\title{
Plantation management and bamboo Resource economics in China
}

\author{
Manejo de plantaciones y economía de los recursos de bambú en China \\ ${ }^{\bullet}$ Fidel Antonio Troya Mera ${ }^{1,2}$, Chenyang $\mathrm{Xu}^{3}$ \\ ${ }^{1}$ Student of Silviculture. Forestry department. BJFU, Beijing Forestry University. Tsinghua East Road No.35. \\ P.C.100083. Haidian District, Beijing, P. R. China. Tel+59313661195879. ^fideltroya68@hotmail.com \\ ${ }^{2}$ Facultad de Ciencias Ambientales, Universidad Técnica Estatal de Quevedo. Av. Quito km, 1.5 vía a Santo Domingo \\ de los Tsáchilas. EC-120501. Quevedo, Ecuador. \\ ${ }^{3}$ Professor of the forestry department. BJFU, Beijing Forestry University. Beijing, P. R. China. cyxu@bjfu.edu.cn
}

\begin{abstract}
B amboos constitute a very important and versatile resource worldwide. A lot of Asian, African and South American people rely on bamboo products for their housing and farming tools. Meanwhile, the shoots of these plants are regarded as vegetables in East and South-East Asian nations. China has the greatest bamboo forest area (extension) and the largest number of bamboo species (more than 590 species), many of them with significant economic importance, being Moso bamboo (Phyllostachys edulis), the most important bamboo species in China, due to its usage not only as timber but also for food. China has paid unprecedented attention in recent decades to bamboo forest management. The vast economic profits derived from silviculture have contributed much to rural development and poverty alleviation. Bamboo industry has become the pillar of economy in mountainous areas. Besides being a tool for poverty alleviation in rural areas, bamboo plantations are also a significant carbon sink and a key option to mitigate land degradation. This paper highlights such aspects as bamboo silviculture (fertilization, pruning, thinning, irrigation, shoot and timber harvesting) its domestic and international applications (timber, plywood, food, paper, fuel, housing, etc.) in daily life, and its current role in Chinese industry and economy, without particular reference to any of its species.
\end{abstract}

Key words: Bamboo economy, bamboo silviculture, shoots, timber, Phyllostachys edulis.

Recibido: 26-diciembre-2013. Recibido en forma corregida: 6-enero-2014.

Aceptado: 28-febrero-2014.

Publicado como ARTÍCULO DE REVISIÓN en Ciencia y Tecnología 7(1): 1-12

Enero-Junio de 2014

ISSN 1390-4051 impreso; ISSN 1390-4043 electrónico

(C) Ciencia y Tecnología. UTEQ. Quevedo-Ecuador

\section{Resumen}

$\mathrm{n}$ el mundo, los bambúes constituyen un recurso Cmuy importante y versátil. Mucha gente asiática, africana y sudamericana depende de este producto para sus viviendas y herramientas agrícolas. Al mismo tiempo, los brotes de caña son considerados como verduras en países del este y sureste asiático. China posee la mayor extensión de bosques de bambú y el mayor número de especies (más de 590 especies), muchas de ellas con gran importancia económica, tales como Moso bambú (Phyllostachys edulis), la más importante en China no solamente para madera sino también para alimento. En las últimas décadas China ha prestado una atención sin precedentes al manejo de estos bosques. Los enormes beneficios económicos derivados de la silvicultura del bambú han contribuido mucho al desarrollo rural y mitigación de la pobreza. La industria de caña se ha convertido en el pilar de la economía en las zonas montañosas. Además de ser una herramienta para la mitigación de la pobreza en zonas rurales, estas plantaciones son también un importante sumidero de carbono y una opción clave para mitigar la degradación del suelo. Independientemente de la especie, en el presente artículo se ilustran aspectos tales como silvicultura (fertilización, poda, raleo, riego, cosecha de brotes y madera, etc), así como también aplicaciones domésticas e internacionales del bambú en la vida diaria (madera, contrachapados, comida, papel, combustible, vivienda, etc.), y su rol actual en la industria y la economía china.

Palabras clave: Economía del bambú, silvicultura del bambú, brotes, madera, Phyllostachys edulis. 


\section{INTRODUCCIÓN}

$\mathrm{B}^{\mathrm{a}}$ amboo is a woody grass belonging to the sub family Bambusoideae of the family Poaceae (Gramineae). It is recorded to be the fastest-growing woody plant on the earth since culms of some species, in just 4 months, can reach $40 \mathrm{~m}$ in height and $30 \mathrm{~cm}$ in diameter. It is sufficiently cheap and plentiful to meet the vast needs of human populace from the "child cradle to the dead man's bier" that is why sometimes it is known as "poor man's timber" (Diver, 2001).

Bamboo is widely distributed in Southeast Asia, Africa, and Latin America. Approximately 3.2\% of the world's total forest area (37 million hectares), is bamboo forest. It is estimated that worldwide there are over 1200 species under 87 genera of bamboo, with a natural distribution across a broad range of environments (humid tropical, subtropical and temperate region) on all continents except Europe and Antarctica (Ram et al., 2010; Hogarth and Belcher, 2013). In addition, bamboo is an adaptable plant, some species being deciduous, others are evergreen, and especially, some species seem to be able to adapt to much different habitats when necessary (Ha, 2010).

Bamboo is becoming popular as an excellent substitute for wood in paper industries, domestic commodities, cottage industries, board and charcoal (Lobovikov et al., 2007). The people of Asia, Africa and South America are dependent on it for their house construction and agricultural implement. Bamboo shoots are eaten as vegetable mostly in South-East and East Asian countries. As a major non-wood forest product and wood substitute, bamboo is of increasing interest to ecologists owing to its rapid growth and correspondingly high potential for mitigating climate change. If well-managed, bamboo plantations can conserve soil and water, and improve soil fertility and local climate as well.

As the most important non-wood forest product and wood substitute, bamboo is playing an increasingly important role in minimizing timber demand pressure on China's forest resources. With a long history of production and utilization of bamboo, China is one of the countries with the richest bamboo resources and largest area of bamboo forest, and this country has paid unprecedented attention in recent decades to bamboo forest management (Song et al., 2011).

This article presents a review of bamboo resources in China, the management of bamboo plantations as well as the economic role of products obtained from bamboo timber and edible shoots. The environmental importance of bamboo forests is also addressed.
Climate and soil conditions for the growth of sympodial and monopodial bamboos

Bamboo consists of two general types: clumping (also called sympodial or pachymorph) and running (also called monopodial or leptomorph). The clumping types are typically of tropical or subtropical origin and therefore cannot withstand freezing temperatures. Running bamboo, which includes the most important genus of temperate climate species, Phyllostachys, can withstand occasional low winter temperatures (Diver, 2001).

Sympodial bamboos have higher demands for temperature and humidity, and in China they are mainly distributed to the south of the Nanling mountains and in the Sichuan basin. Different species have different requirements for humidity and temperature. Dry and barren, rocky or very clayey soil is not suitable for sympodial bamboos. Monopodial bamboos prefer sites with warm and moist climate. In China, for instance, their central distribution area is located between the Yangtze River and the north of the Nanling mountains (Xiao and Yang, 2001).

\section{Worldwide bamboo origin, distribution and extension}

Bamboo is common in Asia, Africa, and Latin America, but its origins lie in Southeast Asia. The geographical distribution of bamboo generally depends on climate. It adapts easily to a range of climatic and soil conditions, and is therefore widely distributed in the tropical and subtropical zones between approximately $46^{\circ} \mathrm{N}$ and $47^{\circ} \mathrm{S}$ latitude, reaching elevation as high as $4000 \mathrm{~m}$ in the Himalayas and parts of China. Normally, bamboo thrives at temperature range of 8.8 to $36^{\circ} \mathrm{C}$, but some species can even grow in cold climate with temperature of about $-20{ }^{\circ} \mathrm{C}$. Rainfall plays a very important and dominating role in the distribution and growth of different species. Bamboo prefers regions of high rainfall ranging from about $1270 \mathrm{~mm}$ to about $6350 \mathrm{~mm}$ or even more (Ha, 2010; Ram et al., 2010; Song, et al., 2011).

Geographic distribution of bamboo worldwide may fall into three major regions; namely, the AsianPacific Region, the Americas Region, and the African Region (Figure 1). About $80 \%$ of bamboo forest lands and species in the world are distributed in Asia and Pacific regions. Within its tropical and temperate climates, Asia has many advantages for bamboo growth accounting for more than 900 species in 40-50 genera. Many Asian countries such as China, India, Myanmar, Indonesia, Thailand, and Vietnam are very rich in bamboo resources. 


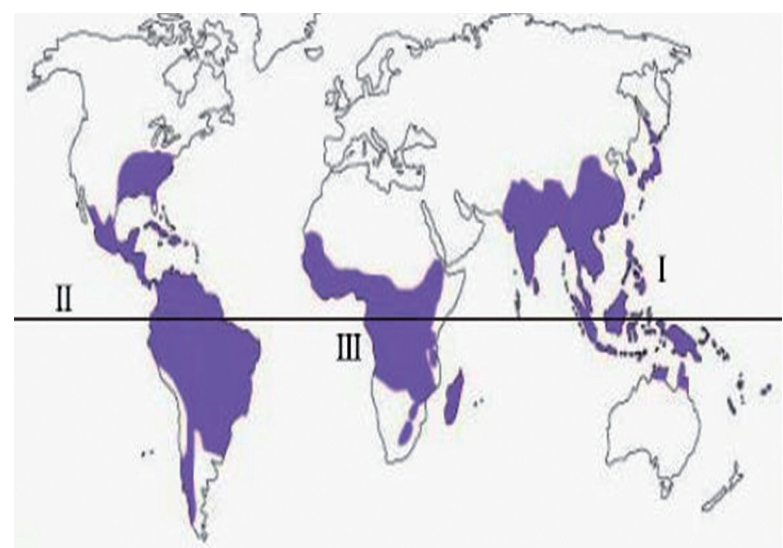

Figure 1. A sketch map of World Bamboo Distribution. The Asian-Pacific Region (I); The America's Region (II); The African Region (III)

The major bamboo producing countries in Asia are India and China; they together account approximately $70 \%$ of the bamboo in Asia. The American Region which involves the continents of South America, Central America and North America, has a high biodiversity of bamboos with approximately 400-500 species, among them about 300 species in 20 genera are woody bamboos. Africa has barely about 40 species but it is worth mentioning that this continent, though rather poor in bamboo florae with only a few native species, has large areas of natural bamboo forests (Lobovikov et al., 2007; Ha, 2010; Yang and Hui, 2010).

Bamboo resources and forest distribution in China Bamboo forests occur over a wide geographic distribution in China, reaching south to Hainan Island, north to the Huanghe River valleys, east to Taiwan Island, and west to Nyalam in Tibet. Due to its vast territory, complex terrain, and diverse climate, China has the richest bamboo resources in the world with approximately 39 genera and more than 590 species (Yang and Hui, 2010; Song et al., 2011; Yue, 2012).

In China, bamboo forests cover a total area of 7.2 million ha, of which 4.2 million ha are pure bamboo stands (plantations) and 3 million ha are mixed and mountain natural bamboo stands. China's bamboo forests are mainly distributed in southern provinces, where the climate and geographic conditions are favourable for timber plantations and bamboo forests. Bamboo is mainly found in Anhui, Fujian, Guangdong, Hubei, Hunan, Jiangxi and Zhejiang provinces in the East and Chongqing, Guangxi, Guizhou, Sichuan and Yunnan provinces in the West (Figure 2) (Wang, 2006; Engler et al., 2011). More than half of the total Chinese bamboo forest area is distributed in Fujian, Jiangxi and Zhejiang provinces (Song et al., 2011).

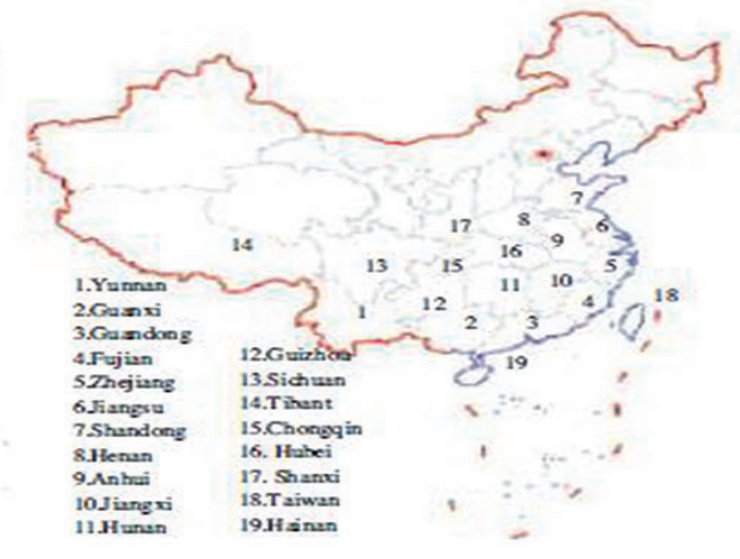

Figure 2. China's bamboo growing province map, Source: China's bamboo (2010)

Since the 1990s, the area of bamboo forest has been rapidly increasing at a rate of about 50,000 ha per year (Figure 3) (Lobovikov et al., 2007).

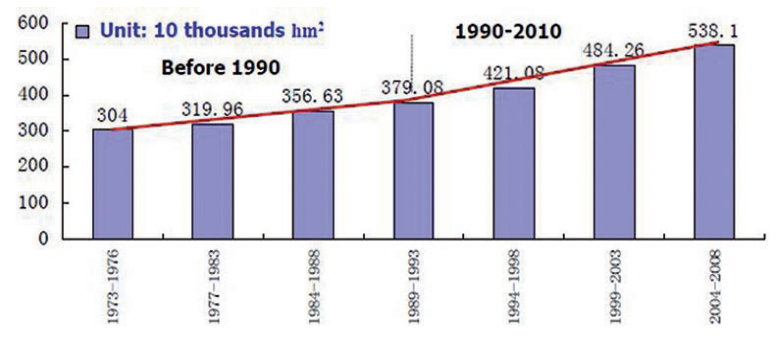

Figure 3. The change of pure bamboo forest area in China from 1976-2008, Source: Yue Yongde (2012)

China today has by far the largest bamboo sector globally. It has been responsible for most of the innovation in bamboo processing, which has been matched by the expansion and productivity increases of its bamboo forests (Yi and Henley, 2010).

\section{The bamboo star in China}

Moso bamboo (Phyllostachys heterocycla var. pubescens or Phyllostachys edulis) is called "MaoZhu" in China. In this country, it is the most important bamboo species (Figure 4) and in turn the third most important plant species for timber production next to Pinus massoniana and Cunninghamia lanceolata (Chinese Fir). Moso bamboo is very good for shoot production and this species plays a very important environmental role as well (Fu, 2001).

Since the 1950's, the area of Moso bamboo forest increased from 1.5 million hectares in 1957 to 5 million hectares in 2007 through natural expansion and plantation establishment. This expansion represents one of the fastest growing areas of forestry in China, 
and has largely been led by the state, which has made the major decisions and policies related to the forestry industry through central planning of the economy (Yi and Henley, 2010).

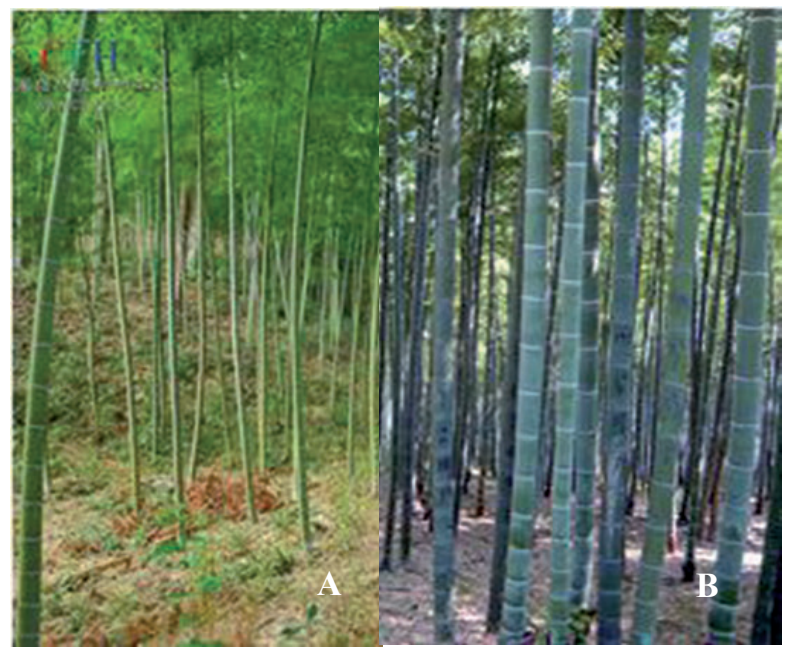

Figure 4. Moso bamboo plantations: Young stand (A); Adult stand (B)

\section{Economic importance and benefits of bamboo}

Bamboo properties of fast growth, renewability, strength and the high number of applications derived from it provide mankind a wide range of goods and services. The potential of bamboo is deeply rooted in knowledge and tradition in Asia, South America and Africa, where it has held an integral part in people's lives as far back in history as records go, and it has over a thousand documented uses from building materials to food. The number of known uses is constantly expanding today, as advances in industrial techniques allow processing of bamboo into new shapes and forms (Yi and Henley, 2010; Song et al., 2011).

Bamboo grows much faster than timber tree species, it requires less intensive management and expertise. It can be harvested annually without depletion and deterioration of the soil; it can grow on marginal land not suitable for agriculture and regenerates easily; it is easier to harvest and transport than timber tree species since with bamboo such activities don't require specialized equipment or vehicles; it splits easily for weaving and is thus easy to handle also for women (Wang, 2006; Lobovikov et al., 2007).

\section{A resource for poverty alleviation in China}

Bamboo forests are mostly cultivated as collective forests in the hilly areas of southern China. The huge economic benefits derived from bamboo forest management have contributed much to rural development and poverty alleviation. Bamboo generates approximately $30 \%$ to $40 \%$ of a farmer's income. The bamboo industry has become the pillar of economy in mountainous area (Song et al., 2011).

Processing normally does not require highly skilled labour or special qualifications and can be started by rural poor communities at a minimal cost. Bamboo offers significant advantages to low-income rural communities with little access to investment capital or technology (Wang, 2006; Lobovikov et al., 2007).

The gains from the rising bamboo sector are impressive. Economically, the high returns from the development of the sector have mainly accrued to rural areas. The sector has responded well to development planning: 'bamboo counties' which have diversified into developing different bamboo industries (furniture, flooring, shoots, charcoal and so on) have led to viable rural industries which have had important multiplier effects in raising local residents' incomes (Yi and Henley, 2010).

\section{Materials AND Methods}

ince it is an informative article, it is a compilation and drafting of various scientific articles, most of which were published in indexed journals. The collected information is reliable and quite recent. Firstly, an introduction about the importance and distribution of bamboo worldwide and locally is presented. Secondly, a description of the main silvicultural techniques for bamboo plantations in China is made, so several management techniques for adults and young plantations are explained. Subsequently, the main domestic and international applications of bamboo products are described, highlighting bamboo timber and bamboo shoots. Finally, we briefly present data regarding to the impact of bamboo trade on the Chinese economy in recent years.

\section{Results}

\section{Management of bamboo plantations Management techniques for young stands}

Fertilization. Although bamboo can survive in poor soils, it is advantageous to apply fertilizer for optimum growth. Fertilizer can be applied at the rate of 200-300 g per plant after planting and every 3-4 months thereafter. As the clumps become thicker, the rate of fertilizer should also be increased progressively. The application of fertilizer can be scheduled at the start and at the end of the rainy season in areas having pronounced dry and rainy seasons. Organic fertilizers such as compost and manures may also be used in combination with or as a substitute to synthetic fertilizers (Bareja, 2010). 
Fertilization should be made some time soon after planting if the situation allow, inorganic fertilizers will be more immediately favorable to the vegetative growth of bamboo plantlets. The following fertilization application rate is recommended for each hectare of bamboo; nitrogen: 20-30 kg; phosphate: 10-15 kg; silica: $20-30 \mathrm{~kg}$. The best timing for the first application of inorganic fertilizer is 1 month after planting when the transplanted plantlets have resumed growth, the second fertilization may be performed 4 months later, and then organic fertilizers can be added 6 months later.

In view of the high and rising cost of inorganic fertilizers, manures and mixed compost can also be applied to effectively stimulate the development of the bamboos, which have a high demand for the element silica. Therefore, fertilizers with adequate silica content should be applied to bamboo stands for better growth. The most convenient way is to use the composted bamboo leaves collected from the old bamboo stands (Yang and Hui, 2010).

Generally speaking, bamboo plants consume 500-700 g of N, 100-150 g of P and 200-250 g of K from the soil per $100 \mathrm{~kg}$ of bamboo shoots produced Accordingly, the nutrient requirements of plantations yielding $15,000 \mathrm{~kg}$ fresh shoots per hectare per annum can be met by applying $75-105 \mathrm{~kg}$ of N, $15-22.5 \mathrm{~kg}$ of $\mathrm{P}$ and $30-37.5 \mathrm{~kg}$ of $\mathrm{K}$ per hectare each year. Chemical fertilizers are usually applied two to four times during the shooting stage at intervals of one or two months. It is applied in 10-15 cm deep drills that are prepared about $50-60 \mathrm{~cm}$ around the clump. Alternatively, $37,500 \mathrm{~kg}$ of organic fertilizers such as barnyard manure or beancake and rapecake can be used. Application in the drill is best done in combination with soil loosening in the winter months. When green manure is employed as fertilizer, it can be applied at 75 tonnes per hectare, and can also serve as a protective layer to reduce evaporative moisture loss (Xiao and Yang, 2001).

Intercropping. It is wasteful to allow the interrow spaces to become idle. Intercropping in newly established bamboo stands increases productivity and economic returns from the land. To maximize land utilization, it is recommended that early-maturing cash crops should be intercropped during the early years before harvesting of the mature culms. Cash crops may consist of annual (e.g. corn) or perennial crops (e.g. banana).

Soil-preparing and soil-loosening. Weeds should be controlled effectively to avoid their competition with bamboos for soil moisture and nutrients in young stands without intercropping. Weed control in mature stands may be achieved in a single operation. Soil-loosening in bamboo plantations is important, as maintaining a good soil structure in the stand will help the growth of shoots and the root system, as well as improve water conservation. Soil loosening is done once or twice a year, it involves surface tilling to a depth of 15 to $20 \mathrm{~cm}$ (Bareja, 2010).

\section{Management techniques for adult stands}

When the young forest begins to produce shoots in large numbers, it has reached its adult stage. Measures to achieve high yields as the forest becomes mature mainly consist of improving growing conditions for the forest and managing its population structure.

Cultivation and manuring. With organic fertilizer as the dominant part, manure applications can be of tender grass or rape cake in summer and fall, supplemented with a fertilizer such as urea in spring and summer. Application can be done 1-3 times a year (usually just before new shoots emerge, then again when height growth stops, and again just before cold weather begins) and at $10-15 \mathrm{~kg} / \mathrm{mu}(150-225 \mathrm{~kg}$. per hectare) each time. Soil cultivation and manure applying can improve the physiochemical properties and nutritive conditions of the bamboo forest soil to attain the objective of high yields.

Pruning. The lower branches of the culms should be removed to enhance farm visibility, promote air movement and facilitate ease in fertilization and harvesting. Partial pruning is also recommended to allow passage between clumps especially when planted with narrow spacing. Sufficient thicket should be retained to hold the culms erect.

Thinning. Thinning or removal of dead, damaged and defective culms is done 3 years after planting. This will promote visibility and provide more space for the growth of new shoots. In large clumps, removal of young shoots with narrow diameter is recommended. These will develop into small culms but will likely become hindrances during harvesting (Bareja, 2010).

Digging out old balls. When running bamboos are felled, their root balls will generally remain underground for up to 10 years before thoroughly decomposing. These undecayed culm bases are as hard as rocks and can impede growth of the rhizomes so that the stand becomes thinner and sparser with each passing year. New culms may still keep shooting, but year after year the bamboos may become increasingly thinner and their yield may fall because their roots, pinched between dried root balls, are unable to stretch into soil for water and nutrition. So getting rid of old balls and rhizomes in a timely manner is regarded as a key to regeneration, rejuvenation, and improved harvest from the bamboo 
stand.

Irrigation and drainage. Mostly bamboos are water loving but intolerant of being waterlogged. So adequate irrigation is a must in dry seasons while drainage may be a necessity in wet seasons, otherwise growth of the bamboo stand will be negatively affected.

Shoot thinning and shoot protection. Shoot thinning means digging out of weak and small shoots. Research indicates that weak and small shoots are inevitable and doomed to die if not dug out in a timely manner. Every year in a stand only $10 \%-40 \%$ of the shoots grow into mature bamboo culms while $60 \%-90 \%$ abort or remain small. The higher the yield of a bamboo stand, the more dead and small shoots it will tend to have. It is impossible to wipe out all dead shoots; it is natural for the stand to have big and small, strong and weak shoots every year. In production, therefore, we ought to preserve strong shoots for propagation but dig out or take the thin and small for food (Yang and Hui, 2010).

Shoot harvesting. Studies in China using Phyllostachys pubescens have shown that there is a definite advantage to harvesting the shoots while they are still underground with sheaths just appearing above ground. Protein and amino acid content are highest when shoots are still underground (Diver, 2001).

There are three types of shoots; spring or summer shoots, winter shoots (very tender) and rhizome shoots. Most bamboos produce new culms once each year, usually in the spring or autumn (Figure 5). By careful management of bamboo plantations a maximum number of shoots can be encouraged to grow each year. They can then be harvested when they are about 15- 30 $\mathrm{cm}$ long, depending on the species.

Sympodial bamboos produce shoots from May to October with most production in July to August. Edible shoots should be harvested before they become tough. Any delay will result in loss of quality and quantity. Generally, the initial shoots and most of those produced in the summer are harvested, but those produced towards the end of the shooting period will be selected and retained as mother culms.

In China, modern bamboo silvicultural practices for producing shoots started in the 1950's. A series of systematic silvicultural and processing techniques has been developed, which includes high-yielding cultivation and management of natural stands and plantations and establishment of factories for preserving and processing bamboo shoots (Xiao and Yang, 2001).

Culm harvesting. Mature culms of desirable sizes are ready for harvest at 3-5 years after planting. Based on

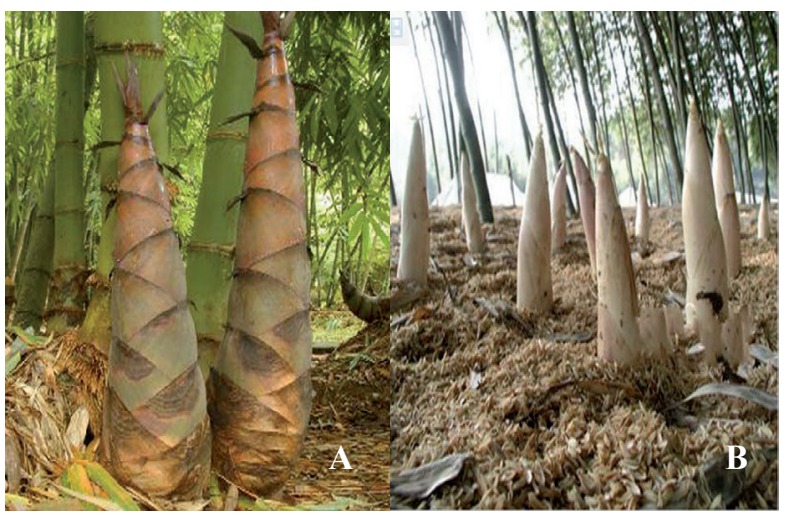

Figure 5. Bamboo shoots in the field: Shoots of sympodial bamboo (A); Shoots of monopodial bamboo (B)

observable traits, the following indexes are generally used in identifying a mature culm: 1) Leaf sheaths are naturally detached from the culm; 2) The bark of the culm has a glossy texture; 3) The bark of the culm approaches bronze-like or yellowish colour.

Harvesting is preferably done during dry months. This timing of harvesting is traditionally practiced by farmers to prevent or minimize attack on the culm by post beetle (bokbok). Scientifically, this is attributed to low starch content of the culm. Harvesting during the dry season (summer) is also beneficial because shoots rarely grow during this period. Also, the removal of culms will promote the growth of new shoots, in time for the incoming rainy season. The cut should be made as close as possible to the base (Bareja, 2010).

\section{Management changes in bamboo plantations}

As the bamboo sector has grown over the last few decades, management practices in bamboo forests have changed. With the rapid development of the bamboo sector, further research into science and technology of bamboo cultivation, accompanied by field trials and the development of prescriptive management techniques, has led to the introduction of more scientific management of these forests with the main aim of raising annual yields.

The principal means of increasing yields is to increase the density of bamboo culms per unit of land, effectively creating monocultures. This means there are many more culms for harvest per year. This is achieved primarily through active clearance of other vegetative species, including trees, shrubs and undergrowth. The aim of this is to provide greater space, nutrients and water for the bamboo.

These management techniques have been approved and promoted by the relevant forestry bodies, and have been included into a standard on bamboo management. This has lead to their greater adoption at a regional 
scale and it is estimated that over 4.2 out of 7.2 million hectares of natural mixed bamboo and broad-leaved or coniferous evergreen forests are at risk of conversion to monoculture forests (Yi and Henley, 2010).

In Zhejiang province better management practices have been put into practice. The Chinese government has recommended several bamboo management measures such as reclaiming, soil tilling and weeding, fertilizing, pest control, digging shoots and top log cutting. For some of these, such as the use of fertilizers, the government provides incentives for the adoption of those techniques. Even then, use of fertilizers is not common and is practised only on intensive production sites where farmers have sufficient capital. The local government also offers technical training courses for farmers and sets up model bamboo plantation farmer households.

Farmers usually carry out soil tillage, weeding, toplog cutting and 'nieyou'. Top-log cutting and nieyou are bamboo management techniques specific to Zhejiang province. Top-log cutting involves cutting a third off the top from one-year old bamboo culms. This practice protects bamboo from heavy snow stress in winter and allows more light to penetrate bamboo stands. The cut portion is used for broom-making. Nieyou is another efficient bamboo management practice, wherein farmers write dates and their names on one-year-old bamboo culms using a special indelible ink. This practice makes it easy to identify the age and owner of bamboo during management and harvest seasons.

Harvest regulation. It was imposed by the government on contract land to avoid overexploitation of bamboo resources, and has played a significant role in maintaining bamboo resources and encouraging intensive bamboo cultivation. According to the regulation, the post-harvest number of standing culms per ha should not be less than 1,650. The harvests are monitored when farmers sell bamboo. For Moso bamboo, certain additional measures such as a strict harvest season (from September 15 to March 31) and culm maturity (culms 4 years or older) are in place (Zhong et al., 1998).

\section{Bamboo uses and bamboo economics}

Bamboo uses and products. Bamboo was discovered, adopted and developed by humans in ancient times. The first scripts of bamboo were written in China more than 6,000 years ago. Bamboo pens, brushes and musical instruments were invented 3,000 years ago. The first paper was produced from bamboo in China in the ninth century. Bamboo culture is an essential part of human history and civilization, especially in Asia (Lobovikov et al., 2007).
At present, bamboo is an extremely versatile material (Diver, 2001). Apart from the use of shoots for food, the other bamboo organs can be used as follows: Culms: top parts (toothpicks, skewers, etc); middle upper parts (woven articles, handicrafts, bamboo curtains, laminated panels, etc); middle lower parts (laminated furniture, floorings); base parts (charcoal, bamboo vinegar); processing residue: energy; bamboo particleboard, bamboo viscose fiber textiles. Leaves: fodder, pigments, medicine, beverage, etc. Twigs: brooms. Rhizome: handicrafts (Yue, 2012).

Nowadays, bamboo has three principal uses. Domestic use in the farm, commercial production, and conservation, landscape and ornamental uses.

Domestic use in the farm. Vegetable stakes, banana props, trellis poles, fencing, shade laths, carts, etc (Diver, 2001); commercial production: Bamboo has two clearly differentiated uses in China: bamboo culms (for timber) and bamboo shoots (for food) (Wang, 2006).

Bamboo for timber. During the last 15-20 years, bamboo has developed as an exceptionally valuable and often superior substitute for wood (Lobovikov et al., 2007). The bamboo culm or pole is ideal as an inexpensive source of material for housing and construction, concrete reinforcement, scaffolding, bridges, furniture, handicraft, fishing poles, musical instruments, pulp and paper manufacture, traditional toys, tools, cloths, fuel, industrial products such as bamboo tiles and plywood, panelling, flooring, roofing, etc. (Diver, 2001; Bareja, 2010).

Developments in science and technology are constantly revealing new fields for bamboo uses. Research in bamboo plywood started abroad in the 1940 's, and production lines of bamboo fiberboard and bamboo veneer were established in quick succession. In China, however, bamboo processing has focused for a long time on traditional items that are technologically simple and limited in variety.

Industries based on replacing wood with bamboo have already taken shape in China. To replace wood with bamboo, the major approach is to mass produce bamboo based panels as substitutes for various wood based panels. At present the main products include woven bamboo plywood, bamboo laminated plywood, bamboo veneer panels, overlayed decorative boards, bamboo parquet flooring, bamboo wood composite panels, bamboo flakeboard, bamboo shaveboard, corrugated bamboo board, and bamboo fiberboard (Yang and Hui, 2010).

Bamboo housing. Bamboo houses are quite common in many countries including China, India, Bangladesh, 
Indonesia, Philippines, Costa Rica and Ecuador. Over one billion people live in traditional bamboo houses. These buildings are usually cheaper than wooden houses (bamboos are among the cheapest building materials), light, strong and earthquake resistant, unlike brick or cement constructions.
Basically, there are three main types of bamboo housing: 1. traditional houses, which use bamboo culms as a primary building material; 2 . traditional bahareque bamboo houses, in which a bamboo frame is plastered with cement or clay; and 3. modern prefabricated houses made of bamboo laminated boards, veneers and panels (Figure 6).

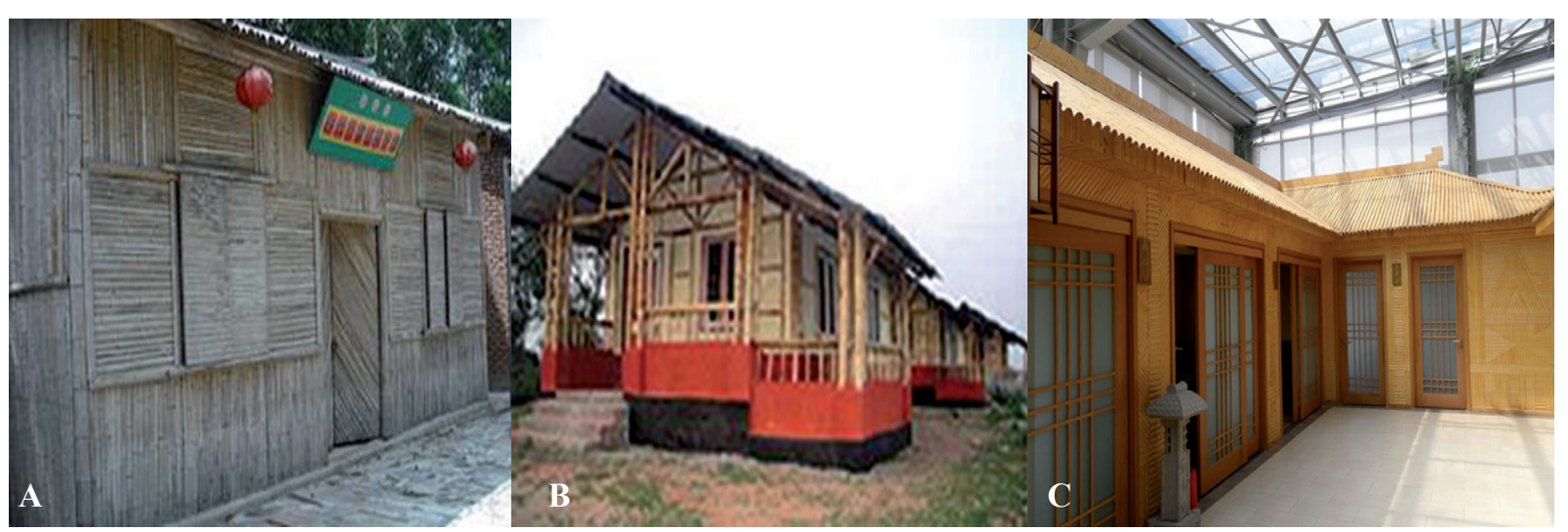

Figure 6. Bamboo houses. Traditional house (A); Traditional bahareque (B); Modern prefabricated house (C)

The favourable characteristics of bamboos make them a suitable material for practically every part of a house (i.e. foundation, flooring, walls and roofs) when treated and used properly. Other key advantages that bamboo construction offers include: easy assembly, prefabrication, simple replacement of structural parts (the bamboo elements can be easily dismantled and reused). New types of prefabricated houses made of engineered bamboo can be packed flat and transported long distances at a reasonable cost. They are better designed and environmentally friendly (Lobovikov et al., 2007; Asif, 2009).

Bamboo pulp and paper. Several bamboo-producing countries, such as China and India, use bamboo in pulp, paper and more recently cloth. Bamboo paper has practically the same quality as paper made from wood. Its brightness and optical properties remain stable, while those of paper made from wood may deteriorate over time. The morphological characteristics of bamboo fibres yield paper with a high tear index, similar to that of hardwood paper. The tensile stiffness is somewhat lower compared with softwood paper. The strain strength is between that of hardwood and softwood papers. The quality of bamboo paper may be improved by refining the pulp.

Bamboo fuel. Bamboo can be converted into three valuable products: bamboo charcoal, oil and gas.
Bamboo charcoal is an excellent fuel for cooking and barbequing. It is traditionally used as a substitute for wood charcoal or mineral coal. Activated charcoal is used as a deodorant, purifier, disinfectant, medicine, agricultural chemical and absorbent of pollution and excessive moisture. China is a leader in its production. At present, Japan, the Republic of Korea and Taiwan are the main consumers, but its importation is rapidly expanding in Europe and North America; bamboo extracts contain valuable elements and can be used in pharmaceuticals, creams and beverages; bamboo gas can be used as a substitute for petroleum (Lobovikov et al., 2007).

\section{Bamboo for food}

Bamboo shoots and other products. Bamboo shoots are young bamboo stems (culms). They have been eaten as a vegetable for thousands of years in many Asian countries and are becoming more and more popular nowadays (Figure 7). China has a long tradition of cultivating, processing and preserving bamboo shoots as food (Xiao and Yang, 2001). They have always been a common ingredient in many Chinese delicacies. Bamboo shoots are now processed into many kinds of food, including fresh shoots, dry shoots, and canned shoots, that are sold around the world. Some new products, such as bamboo candy, bamboo chutney, bamboo canned juice, bamboo beer are also available. Bamboo vinegar is also used as biofertilizer, 
bioinsecticide and as medicine for stomach disorders (Song et al., 2011).

Fresh bamboo shoots are delicious and healthy (Lobovikov et al., 2007). They are brittle, tender, pollution free, low in fat, high in edible fiber and rich in mineral elements. On average, fresh shoots contain about $88.8 \%$ of water, over $3.9 \%$ of protein, $0.5 \%$ of fat, $5.7 \%$ of carbohydrates and $1.1 \%$ of minerals. Bamboo shoots help to keep cholesterol levels low (which is helpful to fight against cardiovascular diseases) and play an important role in preventing colon cancer.
The extractives from bamboo shoots, leaves, and culms include a number of nutrients and other physiologically active compounds such as vitamins, amino acids, flavones, phenols, and organic acids (Song et al., 2011). Amino acid content of bamboo is much higher than found in other common vegetable such as cabbage, carrot, onion and pumpkin. Bamboo shoots contain over ten kinds of mineral elements such as Chromium, Zinc, Manganese, Iron, Magnesium, Nickel, Cobalt, Cupper, especially Potassium, a mineral that helps to keep the blood pressure in its normal values and the heartbeats rhythm constant (Mejía et al., 2009).

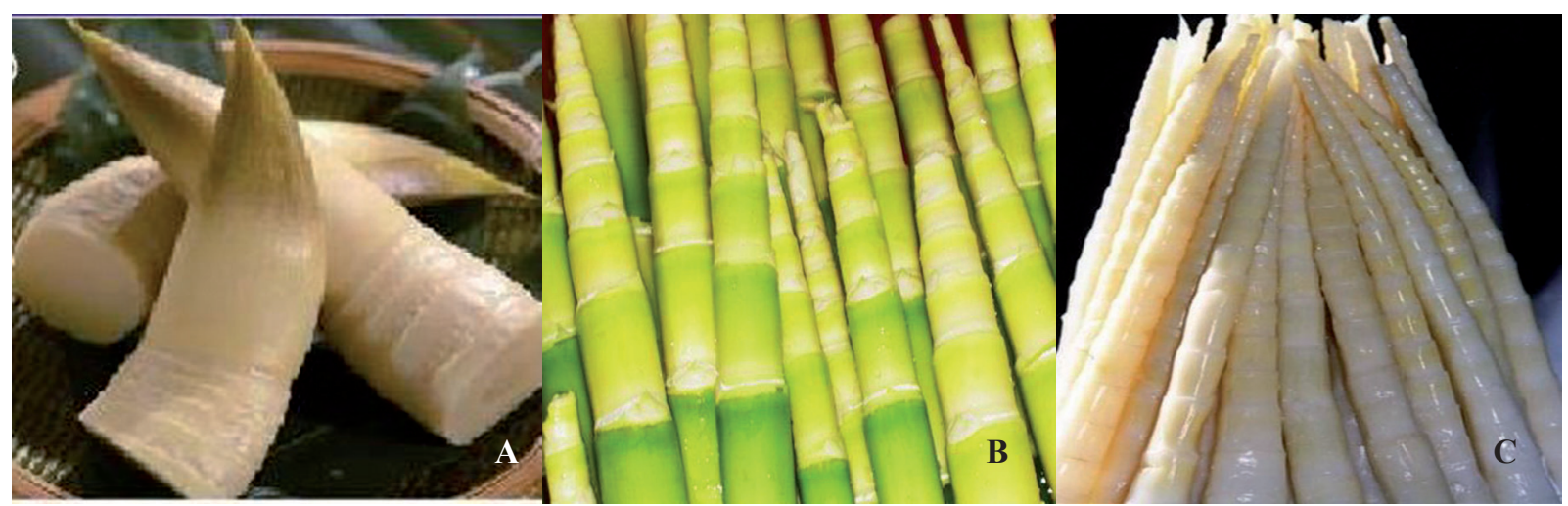

Figure 7. Bamboo shoots for food: Sinocalamus latiflorus (A); Pleioblastus sp. (B and C)

Conservation, landscape and ornamental uses

Ecological impacts of bamboo. Bamboo forests are an important part of the earth's vegetation. Besides bamboos extensive uses, the forests also provide notable ecological benefits and play a vital role in natural eco-systems while having a favorable agroecological impact. Bamboo forests fulfill functions of water and soil conservation, weather adjustment, and air purification while also providing food and habitat for many rare wild animals. Bamboo forests provide food and shelter to large animals (e.g. giant pandas, mountain gorillas and wild elephants) and birds, to the level of the less studied soil organisms, insects, and other plants that together make up the bamboo forest ecosystems. It's cultural value and central position in many of Asia's rural beautiful landscapes demonstrates its high amenity value. With its strong regenerative capacity and a well-developed subterranean system of crisscrossing rhizomes and roots, bamboos planted around lakes or along river banks contribute much to water and soil quality and conservation (Yang and Hui, 2010; Yi and Henley, 2010).

Because of its high ecological and socioeconomic versatility, and especially its great potential for carbon sequestration and its unique role in mitigating climate change, bamboo has been receiving increasing attention in recent decades (Song et al.,
2011). The carbon sequestration ability of bamboo is likely to be second to none and if at all, only to a very few. It has been estimated that one quarter of the biomass in tropical regions and one-fifth in subtropical regions comes from bamboo (Zhou et al., 2005). Bamboo may replace wood in many industrial applications and thereby contribute to the saving and restoration of the world's forests (Lobovikov et al., 2007).

Ornamental value of bamboo. As the Chinese people's favorite plant, bamboo has unique ornamental and aesthetic values in addition to its strong adaptability, extensive utilization, and high economic value (Yang and Hui, 2010).

\section{Economic development and international trade}

Bamboo forests are unique in their ability to meet economic and social objectives of providing timber, development and raising rural incomes rapidly and over a sustained period of time. China's example has shown that by changing their management practices, farmers are able to get richer through significantly increasing the supply of timber to markets without depleting the source of this timber (a relatively uncommon phenomenon in the forestry sector) (Yi and Henley, 2010).

Since the nationwide prohibition on harvesting of natural forests was imposed in 1998, bamboo has rapidly become an excellent substitute for timber, and has 
Troya and Xu, 2014

Table 1. Major economic bamboo species in China

\begin{tabular}{|c|c|c|c|c|c|}
\hline \multirow{2}{*}{ Scientific name } & \multirow{2}{*}{ Rhizome type } & \multicolumn{4}{|c|}{ Main uses } \\
\hline & & Timber & Food & Ornamental & Paper \\
\hline Bambusa lapidea & Sympodial & $\mathrm{x}$ & & & \\
\hline Bambusa sinospinosa & Sympodial & $\mathrm{x}$ & & & \\
\hline Bambusa rigida & Sympodial & $\mathrm{x}$ & & & \\
\hline Bambusa intermedia & Sympodial & $\mathrm{x}$ & & & \\
\hline Bambusa vulgaris & Sympodial & & & $\mathrm{x}$ & \\
\hline Bambusa tuldoides & Sympodial & & & $\mathrm{x}$ & \\
\hline Bambusa multiplex & Sympodial & & & $\mathrm{x}$ & \\
\hline Cephalostachyum pergracile & Sympodial & & & $\mathrm{x}$ & \\
\hline Chimonobambusa quadrangularis & Amphipodial & & & $\mathrm{x}$ & \\
\hline Chimonobambusa szechuanensis & Amphipodial & & & $\mathrm{x}$ & \\
\hline Chimonobambusa utilis & Amphipodial & & & & $\mathrm{x}$ \\
\hline Chimonobambusa yunnanensis & Sympodial & & & & $\mathrm{x}$ \\
\hline Chimonobambusa tumidissinoda & Sympodial & & $\mathrm{x}$ & & \\
\hline Chimonocalamus delicatus & Sympodial & $\mathrm{x}$ & $\mathrm{x}$ & & \\
\hline Chimonocalamus fimbriatus & Sympodial & $\mathrm{x}$ & $\mathrm{x}$ & & \\
\hline Chimonocalamus pallens & Sympodial & $\mathrm{x}$ & $\mathrm{x}$ & & \\
\hline Chimonocalamus makunensis & Sympodial & $\mathrm{x}$ & $\mathrm{x}$ & & \\
\hline Dendrocalamus giganteus & Sympodial & $\mathrm{x}$ & $\mathrm{x}$ & & \\
\hline Dendrocalamus sinicus & Sympodial & $\mathrm{x}$ & $\mathrm{x}$ & & \\
\hline Dendrocalamus latiflorus & Sympodial & & $\mathrm{x}$ & & \\
\hline Dendrocalamus hamiltonii & Sympodial & & $\mathrm{x}$ & & \\
\hline Dendrocalamus membranaceus & Sympodial & $\mathrm{x}$ & $\mathrm{x}$ & & $\mathrm{x}$ \\
\hline Fargesia denudata & Sympodial & & $\mathrm{x}$ & & $\mathrm{x}$ \\
\hline Fargesia robusta & Sympodial & & $\mathrm{x}$ & & $\mathrm{x}$ \\
\hline Fargesia nitida & Sympodial & & $\mathrm{x}$ & & $\mathrm{x}$ \\
\hline Fargesia yunnanensis & Sympodial & $\mathrm{x}$ & $\mathrm{x}$ & & $\mathrm{x}$ \\
\hline Indosasa sinica & Monopodial & $\mathrm{x}$ & & & \\
\hline Phyllostachys edulis & Monopodial & $\mathrm{x}$ & $\mathrm{x}$ & & \\
\hline Phyllostachys nigra & Monopodial & & & $\mathrm{x}$ & \\
\hline Phyllostachys aurea & Monopodial & & & $\mathrm{x}$ & \\
\hline Phyllostachys dulcis & Monopodial & & $\mathrm{x}$ & & \\
\hline Phyllostachys elegans & Monopodial & & $\mathrm{x}$ & & \\
\hline Phyllostachys vivax & Monopodial & & $\mathrm{x}$ & & \\
\hline Schizostachyum funghomii & Sympodial & $\mathrm{x}$ & $\mathrm{x}$ & & \\
\hline
\end{tabular}

Source: China's bamboo (2010) 
entered many markets previously dominated by timber. In 2009, 1.36 billion bamboo culms were harvested, and the gross sales of bamboo amounted to more than 10 billion USD in China, with exports to 177 countries, ranking first in the world (Song et al., 2011). The market for bamboo shoots is very large. Fresh shoots are very popular in many regions, but it is the export market for canned shoots that holds more potential for growth (Xiao and Yang, 2001).

Of the numerous bamboo species many are exploitable for production on a large scale (Table 1). With a vast productive area of $200 \times 104$ hectares, an annual fresh output of $125 \times 104$ tonnes is produced in China. As many stands are less than optimally productive at present, a bit of improvement in management would bring a rise in production (Yang and Hui, 2010).

In China, bamboo industry has reached an annual production value of 13.8 billion USD (Figure 8 ). Bamboo industry provides many employment opportunities for the society. In fact, there are over 5.6 million people directly engaged in this industry. The production of bamboo floorings, bamboo based panels and bamboo charcoals reached 39.4 million $\mathrm{m}^{2}, 3.59$ million tons and 0.14 million tons respectively in 2010 (Yue, 2012).

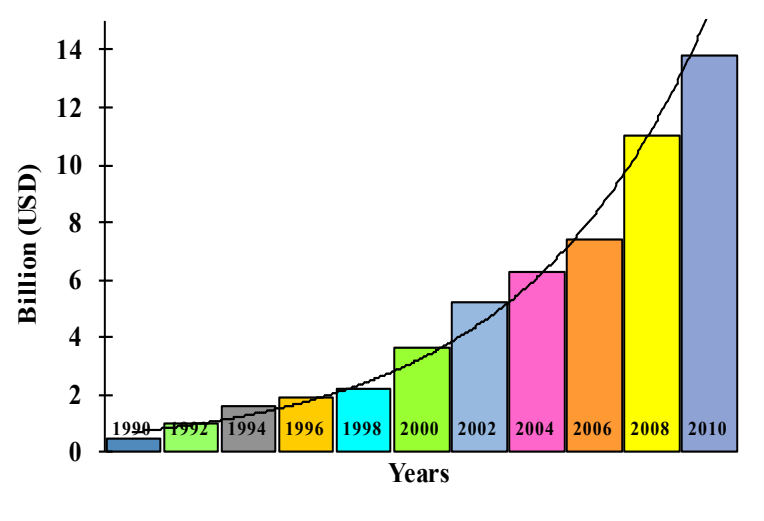

Figure 8. China's bamboo industry production value (billion USD). Source: Yue Yongde (2012)

As a resource which is predominantly used by the rural poor, bamboo has a large potential to boost rural incomes when the markets for it develop. This has been best observed in China's Zhejiang province, where bamboo processing and manufacturing has become a major industry (Yi and Henley, 2010). In Zhejiang province bamboo plantations now under private management are much more productive as some farmers have intensified production. There has been remarkable growth in small, privately owned enterprises as well as in the formation of joint ventures that have increased added value output. Also, traders have opened up export markets and have raised competition (and prices) for raw materials (Zhong et al., 1998).

China alone accounts for about $75 \%$ of the worldwide bamboo exports, followed by other Asian countries such as Thailand, Indonesia, Malaysia and the Philippines (Lobovikov et al., 2007).

\section{Discussion}

$\mathrm{R}$ egarding to bamboo silviculture, undoubtedly China has developed many techniques in correlation to different factors such as species, age, aim of the plantation, etc. Thus, those techniques differ between plantations aimed to get bamboo timber and plantations aimed to get bamboo shoots.

With regard to the use of bamboo products, in China bamboo timber replaces tree timber in many aspects. In fact, in that country there is an extensive use of bamboo timber and bamboo shoots. It is worth to mention that apart from being the world factory nowadays, China takes full advantage of the great versatility of bamboo for a myriad of applications for local use and for export.

With respect to economy, China has improved farmers' survival by managing and exploiting bamboo plantations to maximize the bamboo resource and set up factories in situ which in turn help farmers to overcome poverty. Meanwhile, many of the goods produced in those factories are exported and become a significant income for the country.

\section{Conclusion}

$B^{a}$ amboo not only plays an important role in the daily life of the rural Chinese population but also worldwide it is a very important resource due to its great versatility as wood, food, fuel, etc. Developing countries with suitable lands for bamboo growth should learn from the management techniques (as far as they are deemed suitable) of bamboo plantations used in China in order to make a better use of bamboo resources as a tool for poverty alleviation, and as an alternative for carbon sequestration, taking into consideration social and ecological aspects respectively.

\section{REFERENCES}

Asif, M. 2009. Sustainability of timber, wood and bamboo in construction. (On line). Researched October 16, 2013. Available in http://ebooks.narotama.ac.id/files/Sustaina bilityofConstructionMaterials.pdf 
Bareja, B. 2010. Bamboo production and propagation methods. (On line). Researched March 5, 2013. Available in http://www.cropsreview.com/supportfiles/bambooproduction-and-propagationmethods. pdf

Diver, S. 2001. Bamboo: A multipurpose agroforestry crop. Appropriate Technology Transfer for Rural Areas. Researched September 23, 2013. Available in http://agrisynergy.com/uploads/3/0/4/1/3041271/ bamboo_multipurpose_agroforestry_crop.pdf

Engler, B., Schonherr, S., Zhong, Z., and Becker, G. 2012. Suitability of Bamboo as an Energy Resource: Analysis of Bamboo Combustion Values Dependent on the Culm's Age. International Journal of Forest Engineering 23(2): 114-121.

Fu, J. 2001. Chinese Moso bamboo: Its Importance. BAMBOO. The Magazine of the American Bamboo Society. 22(5): 5-7.

Ha, V. 2010. Growth and quality of indigenous bamboo species in the mountainous regions of Northern Vietnam. Researched April 12, 2013. Available in http://ediss.uni-goettingen.de/bitstream/handle/ 11858/00-1735-0000-0006-B12A-4/tran.pdf.

Hogarth, N., and Belcher, B. 2013. The contribution of bamboo to household incomend rural livelihoods in a poor and mountainous county in Guangxi, P. R. China. International Forestry Review. 15(1):71-81.

Lobovikov, M., Paudel, S., Piazza, M., Ren, H., and Wu, J. 2007. World bamboo resources. Editions INBAR and FAO. 18(1): 7-8 p.

Mejía, A., Gallardo, C., Vallejo, J., Ramírez, G., Arboleda, C., Durango, E., Jaramillo, F., y Cadavid, E. 2009. Plantas del género bambusa: importancia y aplicaciones en la industria farmacéutica, cosmética y alimentaria. Revista de la Facultad de Química Farmacéutica. 16(3): 396-405.

Ram, N., Singh, L., and Kumar, P. 2010. Bamboo plantation diversity and its economic role in North Bihar, India. Nature and Science. 8(11): 111-115.

Song, X., Zhou, G., Jiang, H., Yu, S., Fu, J., Li, W., Wang, W., Ma, Z., and Peng, C. 2011. Carbon sequestration by Chinese bamboo forests and their ecological benefits: assessment of potential, problems, and future challenges. NRC Research Press. 19: 418-428.
Wang, X. 2006. Comparative analysis and policy recommendations on developing bamboo resource tenure systems in Asia and Africa. International Network for Bamboo and Rattan (INBAR) and World Forest Institute (WFI). Portland, Oregon USA. 99 p.

Xiao, J., and Yang, Q. 2001. Bamboo shoot plantation. International Network for Bamboo and Rattan (INBAR). Researched May 3, 2013. Available in http://www.docstoc.com/docs/54222905/BAM BOO-SHOOT-PLANTATION.pdf

Yang, Y., and Hui, C. 2010. China's bamboo. International Network for Bamboo and Rattan (INBAR). 227

Yi, P., and Henley, G. 2010. Biodiversity in Bamboo Forests: a policy perspective for long term sustainability. International Network for Bamboo and Rattan (INBAR). Beijing 100102, P. R. China 59: $26 \mathrm{p}$.

Yue, Y. 2012. Bamboo value chain in China and the importance of research for value chain development. International Center for Bamboo and Rattan (ICBR). Researched February 9, 2013. Available in http://www.worldbamboo.net/wbcix/ presentation/ YueYongde20INBAR.pdf

Zhong, M., Xie, C., Zheng, W., Fu, M., and Xie, J. 1998. Bamboo in Anji, China: a case study of an intensive production to consumption system. International Network for Bamboo and Rattan INBAR. 15: $51 \mathrm{p}$.

Zhou, B., Fu, M., Xie, J., Yang, X., Li, Z. 2005. Ecological functions of bamboo forest: Research and Application. Journal of Forestry Research 16(2): 143-147. 